\title{
The Role of I8F-FDG PET/CT in the Evaluation of Gastric Cancer Recurrence
}

\author{
Mide Kanserinde Yeniden Evrelemede I8F-FDG PET/BT'nin Yeri
}

\author{
Hakan Cayvarlı1, Recep Bekiş², Tülay Akman³, Deniz Altun 4 \\ IOrdu State Hospital, Clinic of Nuclear Medicine, Ordu, Turkey \\ 2Dokuz Eylül University Faculty of Medicine, Department of Nuclear Medicine, Izmir, Turkey \\ 3Tepecik Training and Research Hospital, Clinic of Medical Oncology, Izmir, Turkey \\ ${ }^{4}$ Dokuz Eylül University Faculty of Medicine, Department of Public Health, Izmir, Turkey
}

\begin{abstract}
Objective: F-18-fluorodeoxyglucose positron emission tomography/computed tomography (18F-FDG PET/CT) has been widely used for staging, re-staging and for monitoring therapy-induced changes and response to therapy in patients with various types of cancer, but its utilization for gastric cancer has been limited. This study aimed to assess the diagnostic performance of 18F-FDG PET/CT for detecting recurrence in gastric cancer patients with radiologic or clinical suspicion of recurrence and its clinical impact on making decision.

Methods: We performed a retrospective review of 130 consecutive patients who underwent PET/CT scans for post-treatment surveillance of gastric cancer between January 2008 and March 2012. The mean time between the initial diagnosis of gastric cancer and PET/CT studies was 44 weeks with a median of 18 weeks. The number and site of positive FDG uptake were analyzed and correlated with the final diagnosis by calculating the diagnostic values. We evaluated the diagnostic accuracy of PET/CT for detecting the recurrence in terms of whether or not histology had been SRC/musinous adenocarcinoma. The changes in the clinical management of patients were also evaluated according to the results of PET/CT.

Results: Of all 130 patients, 91 patients were confirmed to have true recurrence. The sensitivity, specificity, positive predictive value, negative predictive value and the accuracy of PET/CT for diagnosing true recurrence on a per-person basis were $91.2 \%, 61.5 \%, 84.6 \%$, $75.0 \%$ and $82.3 \%$ respectively. Final diagnoses were confirmed histopathologically in 59 (45.4\%) of 130 patients and by clinical and radiological follow-up in the remaining 71 (54.6\%) patients. In the subgroup with SRC/mucinous adenocarcinoma differentiation of the primary tumor, there was no statistically significant difference in terms of diagnostic accuracy of PET/CT on a per-person basis. In addition, PET/CT results changed the patients' management in 20 (15\%) cases.

Conclusions: 18F-FDG PET/CT can provide useful information in discriminating true recurrence in patients with suspected gastric cancer recurrence and may have significant impact on clinical decisions/patient management in a considerable percentage of patients. Key words: Gastric cancer, positron-mission tomography, 18F-FDG, disease management
\end{abstract}

\section{Özet}

Amaç: F-18-florodeoksiglukoz pozitron emisyon tomografisi/bilgisayarlı tomografi (18F-FDG PET/BT) pek çok kanser türünde evrelemede, yeniden evrelemede, tedaviye bağlı değişikliklerin ve tedavi yanıtının değerlendirilmesinde yaygın olarak kullanılmaktadır ancak mide kanserinde kullanımı konusunda yayınlar sınılı sayıdadır. Bu çalışmada radyolojik ya da klinik olarak rekürrens şüphesi olan mide kanseri hastalarında 18F-FDG PET/BT'nin rekürrensin değerlendirilmesindeki tanısal etkinliğini ve tedavi kararına etkisini saptamayı amaçladık.

Yöntem: Mide kanseri tanısı ile tedavi sonrası izlemde olan ve Ocak 2008 ile Mart 2012 tarihleri arasında rekürrens şüphesi ile PET/ BT yapıımış 130 hasta geriye dönük olarak değerlendirildi. Hastaların mide kanseri tanısı almaları ile PET/BT çekimleri arasında geçen ortalama süre 44 hafta idi. Patolojik FDG tutulumu izlenen alanların sayı ve bölgeleri incelendi ve kesin tanıları ile karşıllaştıılarak PET/ BT'nin tanısal etkinliği hesaplandı. Taşlı yüzük hücreli ve müsinöz adenokarsinom histolojik türleri ayrıca değerlendirilerek bu grupta PET/BT'nin tanısal etkinliği incelendi. PET/BT sonuçlarının hastanın klinik takip ve tedavi kararına olan etkisi ayrıca incelendi.

Address for Correspondence: Hakan Cayvarlı MD, Ordu State Hospital, Clinic of Nuclear Medicine, Ordu, Turkey

Phone: +90 4522343232 E-mail: hakancayvarli@hotmail.com Received: 29.10.2013 Accepted: 18.06.2014 
Bulgular: Yüz otuz hastanın 91'inde rekürrens saptandı. Hasta bazında değerlendirmede PET/BT'nin duyarlıı̆ı, Özgüllüğü, pozitif öngörü değeri, negatif öngörü değeri ve tanısal doğruluğu sırasıyla \%91,2, \%61,5, \%84,6, \%75,0 ve \%82,3 olarak bulundu. Yüz otuz hastanın 59 tanesinde $(\% 45,4)$ kesin tanı histopatolojik olarak doğrulanırken, kalan 71 hastada $(\% 54,6)$ kesin tanıya klinik ya da radyolojik takip neticesinde ulaşıldı. Taşlı yüzük hücreli ve müsinöz adenokarsinom histolojik türleri ile diğer histolojik türler arasında hasta bazında PET/BT'nin tanısal doğruluğu arasında anlamlı bir fark bulunamadı. Ayrıca PET/BT sonuçları doğrultusunda 20 (\%15) hastanın önceden planlanan takip/tedavi yöntemi değiştirildi.

Sonuç: 18F-FDG PET/BT mide kanseri rekürrensi şüphesi olan hastalarda rekürrensin doğru olarak değerlendirilmesinde faydalı olabilir ve hastaların anlamlı bir kısmında klinisyenin takip/tedavi kararında önemli etkiye sahip olabilir.

Anahtar Kelimeler: Mide kanseri, pozitron-emisyon tomografi, 18F-FDG, hastalık yönetimi

\section{Introduction}

Gastric cancer is the fourth most common cancer worldwide and is the second most common cause of cancer-related deaths $(1,2)$. Radical surgical resection of gastric cancer with lymph node dissection is a considered curative treatment. But its long-term survival is frequently reported as poor. In fact, despite successful surgery, the five year survival rate is approximately $35 \%$, and even with adjuvant chemoradiotherapy in selected patients, the survival rate is $40 \%$ (3). After curative surgery, about $80 \%$ of the patients die within a short period of time from locoregional recurrence (87\%) and/or distant metastasis $(30 \%)(4)$. The reported recurrence rate after curative surgery ranges between $22 \%$ and $60 \%$, increasing with more advanced tumor stage $(5,6)$. It is reported that survival after the diagnosis of recurrent disease was better when recurrence was detected at an asymptomatic stage. Therefore, early detection of recurrence is important in an effort to improve prognosis (7).

The definitive method for diagnosis of gastric cancer recurrence is the pathological confirmation. However, getting adequate tissues is often difficult because either recurred tumor size is very small or it is deeply located or too close to great vessels or organs for needle biopsy. Various methods such as tumor markers, endoscopy or imaging studies can be used to detect gastric cancer recurrence. However each has some limitations: tumor markers cannot localize the recurrent site and endoscopy cannot assign extraluminal recurrence (8). Today the most commonly used imaging method for detection of gastric cancer recurrence is contrast-enhanced computed tomography $(\mathrm{CT})$. It can detect both local recurrence and distant metastasis. But CT has also some limitations on diagnosis of gastric cancer recurrence. Because its diagnostic criteria depends on morphological changes and size measurement but not viability, CT cannot detect the presence of viable tumor tissue and also small lesions like peritoneal implants. In addition, it is difficult to differentiate the post-operational changes from recurrence site $(8,9,10,11)$.

A positron emission tomography (PET) scan is a noninvasive imaging modality that reflects cancer cell metabolism via glucose utilization using fluorodeoxyglucose (18F-FDG) as a tracer (11). Recently positron emission tomography combined with computed tomography (PET/CT) scans are frequently performed for evaluating gastrointestinal tumors; like esophageal and colorectal cancer $(12,13)$. However, at present, limited data is available on the use of FDG PET/ CT in gastric cancer recurrence, and the role of 18F-FDG PET/CT scan in detecting gastric cancer recurrence after curative gastrectomy is unclear $(2,14,15,16)$. Enthusiasm for evaluating FDG PET/CT in this type of cancer has probably been tempered by frequent false negative PET findings due to absence of FDG avidity of signet ring cell carcinoma (SRC) and mucinous adenocarcinomas (17).

In clinical practice, it is hard to make treatment decision when gastric cancer recurrence is suspicious in contrast CT but tissue confirmation is difficult. In this case, additional PET/CT can give us more information on detection of recurrence (15). Therefore, the aims of this study were; (1) to evaluate the diagnostic accuracy of PET/CT in diagnosis of gastric cancer recurrence, (2) to evaluate whether the sensitivity of PET/CT for detection of recurrent disease is related to the histological type of the primary (resected) gastric cancer and (3) to assess its clinical impact on decision making.

\section{Materials and Methods}

From January 2008 to March 2013, 130 consecutive PET/ CT scans of patients with gastric cancer, who underwent FDG PET/CT scan due to radiologic or clinical suspicion of recurrence during follow-up, were retrospectively analysed after a computerized review of the PET/CT database of our institution. If the patients had repeated PET/CT scans, we only analyzed the results of the first PET/CT scans. Of these 130 patients, 96 were male and 34 were female, with a mean age of 61 , ranging from 37 to 84 . PET/CT scan indications of the patients were classified into these three following groups: Group $1(n=112)$ included patients who were suspected of having recurrence by other imaging modalities such as CT or Magnetic resonance imaging (MRI); Group $2(n=5)$ included patients who were suspected of having recurrence because of increase in tumor markers without definite findings on prior imaging modalities or clinical manifestations such as weight loss; and Group $3(n=13)$ included patients who were not suspected of having recurrence, but a PET/CT scan was ordered just for follow-up, based on physicians' request. The mean time between the initial diagnosis of gastric cancer and PET/CT studies was 44 weeks with a median time of 18 weeks and 
a minimum time of 4 weeks. Patients who were followedup for less than 3 months after PET/CT scan and patients with proven second malignancy were not included in this study. Patient characteristics are listed in Table 1.

All scans were performed by a PET/CT system (Philips Gemini TOF 3D Mode, Netherlands). In all patients,

Table 1. Patient characteristics

\begin{tabular}{|c|c|c|}
\hline \multicolumn{2}{|l|}{ Characteristics } & \multirow{2}{*}{$\begin{array}{l}\text { n (\%) } \\
61.6\end{array}$} \\
\hline Age & Mean & \\
\hline & Range & $37-84$ \\
\hline \multirow[t]{2}{*}{ Gender } & Male & $96(73.8)$ \\
\hline & Female & $34(26.2)$ \\
\hline \multirow[t]{4}{*}{ Surgery type } & Total & $65(50)$ \\
\hline & distal subtotal & $26(20)$ \\
\hline & proximal subtotal & $2(1.5)$ \\
\hline & Inoperable & $37(28.5)$ \\
\hline \multirow[t]{3}{*}{ Tumor site } & Upper & $40(30.8)$ \\
\hline & Middle & $42(32.3)$ \\
\hline & Lower & $48(36.9)$ \\
\hline \multirow[t]{2}{*}{ Histopathology } & SRC/Mucinous Adenocancer & $25(19.2)$ \\
\hline & $\begin{array}{l}\text { Non SRC/Mucinous } \\
\text { Adenocancer }\end{array}$ & $105(80.8)$ \\
\hline \multirow[t]{6}{*}{ pT stage } & $\mathrm{Tx}$ & $37(28.5)$ \\
\hline & $\mathrm{T} 1 \mathrm{~b}$ & $4(3.1)$ \\
\hline & $\mathrm{T} 2$ & $9(6.8)$ \\
\hline & T3 & $27(20.8)$ \\
\hline & $\mathrm{T} 4 \mathrm{a}$ & $45(34.6)$ \\
\hline & $\mathrm{T} 4 \mathrm{~b}$ & $8(6.2)$ \\
\hline \multirow[t]{6}{*}{ pN stage } & $\mathrm{Nx}$ & $37(28.5)$ \\
\hline & NO & $19(14.6)$ \\
\hline & N1 & $22(16.9)$ \\
\hline & N2 & $22(16.9)$ \\
\hline & N3a & $18(13.8)$ \\
\hline & N3b & $12(9.2)$ \\
\hline \multirow[t]{2}{*}{ pM stage } & Mo & $83(63.8)$ \\
\hline & M1 & $47(36.2)$ \\
\hline \multirow[t]{8}{*}{ Clinical stage } & $1 \mathrm{~A}$ & $4(3.1)$ \\
\hline & $1 \mathrm{~B}$ & $4(3.1)$ \\
\hline & $2 \mathrm{~A}$ & $11(8.4)$ \\
\hline & $2 B$ & $10(7.6)$ \\
\hline & $3 A$ & $17(13.1)$ \\
\hline & $3 B$ & 19 (14.7) \\
\hline & $3 C$ & $18(13.8)$ \\
\hline & 4 & $47(36.2)$ \\
\hline
\end{tabular}

blood glucose levels were checked, and PET/CT scan was performed if blood glucose level less than $200 \mathrm{mg} / \mathrm{dl}$ had been ensured. The patients were asked to fast for at least 6 hours before undergoing PET/CT scan and 370-555 $\mathrm{MBq}(10-15 \mathrm{mCi})$ of FDG was administered intravenously 1 hour prior to imaging. For the optimal delineation of bowel structures, $400-600 \mathrm{ml}$ of contrast material diluted with water was ingested 1 hour before PET/CT imaging. CT was performed prior to PET, and the resulting data was used to generate an attenuation correction map for PET. Five-milimeter thick sections were obtained at 80 $\mathrm{mA}$ (but adjusted for body thickness) and $120 \mathrm{kV}$ from the skull base to the mid-thigh. All patients were allowed shallow respiration during CT scanning. Next, PET was performed without changing the patient's position with a 2-minute emission acquisition per imaging level and finally the images were reconstructed. PET image data sets were reconstructed iteratively by applying the $\mathrm{CT}$ data for attenuation correction, and coregistered and reconstructed images (5 mm contiguous axial cuts) were displayed on a workstation.

PET/CT images were analyzed by two nuclear medicine physicians. Both readers had knowledge of the clinical findings and of the results of all the available imaging studies. The readers, however, were blinded to the followup data. In the event of diagnostic discordance between the readers, a consensus diagnosis was generated. FDG uptake was defined to be positive qualitatively when a focal FDG uptake was higher than the normal biodistribution of background FDG activity. Focal hypermetabolic activity of anostomotic site or remnant stomach was considered as locoregional tumor recurrence. Focal hypermetabolic activity within the liver which was greater than adjacent normal liver tissue was considered as abnormal. Multinodular or diffuse hypermetabolic activities along the intestine or mesentery were considered as findings of peritoneal carcinomatosis. Diffuse mild activity in the intestinal tract was considered as normal physiologic uptake. In addition, to exclude the physiologic uptake, FDG uptake in the bowel was regarded to be positive only when there was wall thickening of the same bowel at simultaneously acquired CT. Any focal activity in the mediastinum which is higher than mediastinal blood pool was regarded as abnormal. PET/CT images were analyzed for the number and site of positive FDG uptake. Standardized uptake values (SUV) of all positive FDG uptakes were measured. For the purpose of statistical analysis, a true-positive lesion was a lesion which was seen on FDG PET/CT images and found to be positive for tumor tissue at histopathological examination or clinical follow-up. A false-positive lesion was a lesion which was seen on FDG $\mathrm{PET} / \mathrm{CT}$ images but found to be negative for tumor tissue at histopathological examination or clinical follow-up. Moreover, a true-negative lesion was defined when no lesion was seen on FDG PET/CT images and the results of histopathological examination for tumors or clinical follow-up were negative. A false-negative lesion was a lesion that was missed at 
image analysis but was found to be positive for malignancy at histopathological examination or clinical follow-up. The gold standard consisted in radiological and clinical follow-up or histopathological confirmation. A negative clinical and/ or radiological follow-up of at least 3 months starting at the time of the PET/CT scan was required in order to define a lesion as negative. Patient-based classification was performed by considering patients with at least one equivocal or positive PET lesion as positive and all others as negative. If more than one lesion was present in the same patient with discordant diagnostic PET classification, the following rules were used: (a) patients who had at least one true positive PET lesion were classified as true-positive; (b) patients with a false positive and a false negative lesion were classified as false negative. Then, the PET/CT data were correlated with the final diagnosis, by calculating the diagnostic values of $\mathrm{PET} / \mathrm{CT}$. The final diagnosis of recurrence was obtained from the results of histopathological examination after surgery, laparotomy or biopsy, and clinical follow-up of at least 3 months. Clinical recurrence was defined as the detection of recurrent disease by imaging modalities like diagnostic CT or MRI within 3 months of the PET/CT scan. Radiologically, recurrence was defined to be present when a suspicious lesion at CT or MRI showed the interval increment in size during follow-up or a suspicious lesion showed the interval decrement in size after radio/chemotherapy. Recurrence detected more than 3 months after the PET/CT scan was interpreted as a new recurrence. All recurrent lesions were classified into 5 categories: 1) locoregional recurrence; the recurrence in remnant stomach or anostomotic site, 2) regional lymph node recurrence; the recurrence in pancreatic, splenic and perigastric lymph nodes along the lesser and greater curvatures, 3) liver; the recurrence of hepatic metastasis form, 4) peritoneal carcinomatosis, and 5) distant metastasis; the recurrence in lymph node or organ except for the liver. Multiple lesions within one category were considered as a one lesion.

Patient and organ based sensitivity, specificity, positive predictive value (PPV), negative predictive value (NPV) and diagnostic accuracy were calculated by using standard statistical operations. Differences between categorical variables in the population were evaluated using Fisher's exact test. Quantification of tumor metabolic activity was obtained using the SUV normalized to body weight. Mean \pm SD of maximum-pixel SUV (SUVmax) of the lesions were calculated. We have also analyzed the diagnostic performance of PET/CT whether or not the histology was $\mathrm{SRC} /$ mucinous adenocarcinoma on a per-person and per-lesion basis. The influence of PET/CT on patient management and decision making was retrospectively evaluated together with the clinicians from patients' records. The analyses were carried out using SPSS 15.0 (SPSS Inc, Chicago, IL, USA). Tests with $p$ value $<0,05$ were considered as statistically significant.

This study was designed to be a retrospective analysis based on medical records and was approved by the institutional review board of Dokuz Eylül University Hospital. Informed consent was given by each patient included in this study.

\section{Results}

Of 130 patients evaluated in this study, 91 patients were confirmed to have recurrent disease, and the remaining 39 patients were considered as negative for recurrence according to the final diagnosis. When comparison between the PET/CT findings and final diagnosis was made on a perperson basis; among 91 patients having true recurrence, 83 and 8 patients showed positive and negative FDG uptakes respectively. The remaining 39 patients not having true recurrence showed positive and negative FDG uptakes in 15 and 24 patients, respectively. Therefore; the sensitivity, specificity, PPV, NPV and accuracy of PET/CT for diagnosing true recurrence on a per-person basis were $91.2 \%, 61.5 \%$, $84.6 \%, 75.0 \%$ and $82.3 \%$, respectively. Final diagnoses were confirmed histopathologically in $59(45.4 \%)$ of 130 patients and by clinical and radiological follow-up in the remaining 71 (54.6\%) patients.

On the organ-based analysis, in all of 5 groups, the diagnostic accuracy rates were higher than $75 \%$, which was up to $86 \%$ in detecting regional lymph nodes. Sensitivity, specificity, PPV and NPV were also higher than 70\%, except for the specificity of detecting locoregional recurrence and NPV of detecting peritoneal carcinomatosis (Table 2).

When we evaluate distant metastasis group separately, the most common five distant metastasis sites were found as lung, mediastinal lymph nodes, paraaortic lymph nodes, cervical lymph nodes and bones. The diagnostic accuracy values were higher than $75 \%$ in all of these sites, which was up to $92 \%$ in detecting cervical lymph nodes (Table 3) (Figure 1).

In addition, we have analyzed PET/CT data in terms of whether or not histology had been SRC/musinous adenocarcinoma in initial diagnosis. The sensitivity, specificity, PPV, NPV and accuracy in cases of non SRC/ mucinous adenocarcinoma $(n=105)$ were 93.1\%, 65.6\%, $86.0 \%, 80.7 \%$ and $84.7 \%$ respectively, whereas those in cases of SRC/mucinous adenocarcinoma $(n=25)$ were $83.3 \%, 42.8 \%, 78.9 \%, 50.0 \%$ and $72.0 \%$, respectively, when comparison was made on a per-person basis. The diagnostic accuracy of PET/CT was higher in the non SRC/ mucinous adenocarcinoma group but the difference was not statistically significant. Final diagnoses were confirmed histopathologically in 14 of 25 patients in cases of SRC/ mucinous adenocarcinoma and in 45 of 105 patients in cases of non SRC/mucinous adenocarcinoma. We also analyzed PET/CT data in terms of whether or not histology had been $\mathrm{SRC} /$ mucinous adenocarcinoma in initial diagnosis on a perlesion basis. The diagnostic accuracy rates of PET/CT were higher in regional lymph node, peritoneal carcinomatosis, liver and distant metastasis in the non SRC/musinous adenocarcinoma group, and it was higher for locoregional recurrence in the SRC/musinous adenocarcinoma group, 
but the difference between two groups was not statistically significant except for detection of liver metastasis in the non $\mathrm{SRC} /$ musinous adenocarcinoma group $(p=0.02)$ (Table 4).

Overall, therapeutic management was determined by PET/CT results in 20 of 130 patients (15\%). Among these, unexpected or inconclusive lesions were found to be true

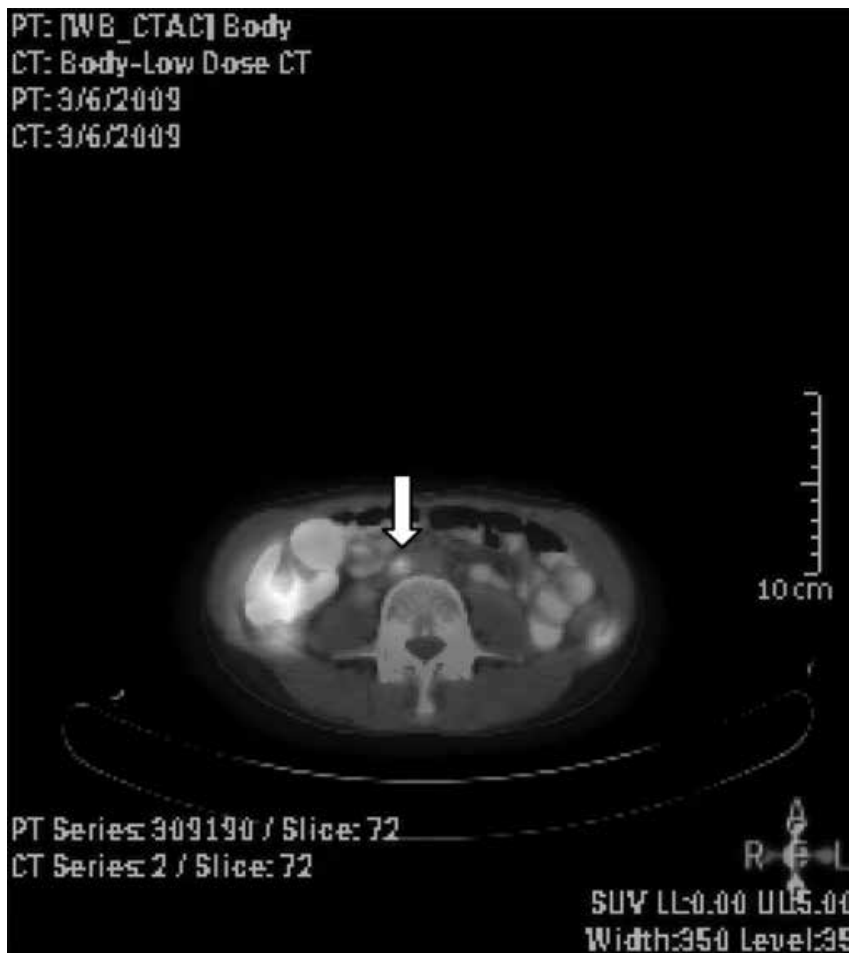

Figure 1. Paraaortic metastatic lymph node (arrow) detected by PET/CT in a patient who was suspected of having recurrence because of increase in tumor markers without definite findings on prior imaging modalities. recurrence or metastatic tumors in 4 patients, for whom surgery or chemotherapy was initiated based on PET/ $\mathrm{CT}$ results. In 10 patients, lesions that were suspected as recurrence before $\mathrm{PET} / \mathrm{CT}$ were regarded as negative because of lack of abnormal uptake, and scheduled treatment was cancelled. Initially planned chemotherapy regimen was altered in 6 patients according to their PET/CT scan results. To conclude, in 19 of 20 patients (95\%) PET/CT had correctly managed therapy/follow-up plans according to the final diagnosis. However, the remaining one (5\%) case with abnormal diagnostic CT scan was revealed to have lesion with no FDG uptake leading to cancellation of previously planned chemotherapy. The results of the changes in patients' management are listed in Table 5.

\section{Discussion}

The optimal method for assessing early recurrence in patients with gastric cancer is unclear (18). Conventional imaging modalities (ultrasonography, CT and MRI) represent the standard for staging and restaging of gastric cancer $(19,20)$. Conventional imaging is noninvasive and is the least costly of the available methods, although it has limited value in differentiating post-surgical changes from local tumor recurrence. Therefore, these techniques have limitations in terms of accurate assessment of recurrence $(18,21)$. Compared with the large number of reports pertaining to PET or PET/CT findings of gastrointestinal tumors such as esophageal and colorectal cancer, there are only a few reports on PET and PET/CT findings of gastric cancer. However, their results were inconsistent. Jadvar et al. reported that FDG PET might be useful in the posttherapy evaluation of recurrent disease. Sim et al. and Park et al. also suggested that PET/CT might have a role of detecting recurrence in post-operative patients with gastric

Table 2. Diagnostic performance of PET/CT on the organ based analysis

\begin{tabular}{lllllll}
\hline & $\mathbf{n}$ & Sensitivity (\%) & Specificity (\%) & PPV (\%) & NPV (\%) & Accuracy (\%) \\
\hline Locoregional & 68 & 93.3 & 47.8 & 77.7 & 78.5 & 77.9 \\
Regional lymph node & 50 & 86.1 & 85.7 & 93.9 & 70.5 & 86.0 \\
Peritoneum & 46 & 76.6 & 87.5 & 92.0 & 66.6 & 80.4 \\
Liver & 40 & 72.7 & 94.4 & 94.1 & 73.9 & 82.5 \\
Distant & 98 & 84.1 & 71.4 & 84.1 & 71.4 & 79.5
\end{tabular}

Table 3. Diagnostic performance of PET/CT in the most common five distant metastasis sites when the distant metastasis group was evaluated separately

\begin{tabular}{lllllll}
\hline & $\mathbf{n}$ & Sensitivity (\%) & Specificity (\%) & PPV (\%) & NPV (\%) & Accuracy (\%) \\
\hline Lung & 52 & 71.4 & 80.6 & 71.4 & 80.6 & 76.9 \\
Mediastinal lymp node & 38 & 96.0 & 38.4 & 75.0 & 83.3 & 76.3 \\
Paraaortic lymph node & 29 & 88.4 & 100 & 100 & 50.0 & 89.6 \\
Cervical lymph node & 13 & 100 & 50.0 & 91.6 & 100 & 92.3 \\
Bone & 11 & 87.5 & 100 & 100 & 75.0 & 90.9
\end{tabular}


Table 4. Diagnostic performance of PET/CT on the patient and organ based analysis in terms of whether or not histology had been SRC/musinous adenocarcinoma

\begin{tabular}{|c|c|c|c|c|c|c|c|c|}
\hline Site & Histopathology & $\mathbf{n}$ & $\begin{array}{l}\text { Sensitivity } \\
(\%)\end{array}$ & $\begin{array}{l}\text { Specificity } \\
(\%)\end{array}$ & $\begin{array}{l}\text { PPV } \\
(\%)\end{array}$ & $\begin{array}{l}\text { NPV } \\
(\%)\end{array}$ & $\begin{array}{l}\text { Accuracy } \\
(\%)\end{array}$ & $\begin{array}{l}p \\
\text { value }\end{array}$ \\
\hline \multirow[t]{2}{*}{ Patient-based } & SRC/mucinous & 25 & 83.3 & 42.8 & 78.9 & 50.0 & 72.0 & \multirow{2}{*}{0.14} \\
\hline & non SRC/mucinous & 105 & 93.1 & 65.6 & 86.0 & 80.7 & 84.7 & \\
\hline \multirow[t]{2}{*}{ Locoregional } & $\mathrm{SRC} /$ mucinous & 12 & 81.8 & 100 & 100 & 66.6 & 83.3 & \multirow{2}{*}{1} \\
\hline & non SRC/mucinous & 56 & 97.0 & 45.4 & 73.3 & 90.9 & 76.7 & \\
\hline \multirow[t]{2}{*}{ Regional lymph node } & $\mathrm{SRC} /$ mucinous & 4 & 66.6 & 100 & 100 & 50.0 & 75.0 & \multirow{2}{*}{0.46} \\
\hline & non SRC/mucinous & 46 & 87.8 & 84.6 & 93.5 & 73.3 & 86.9 & \\
\hline \multirow[t]{2}{*}{ Peritoneum } & $\mathrm{SRC} /$ mucinous & 11 & 66.6 & 100 & 100 & 40.0 & 72.7 & \multirow{2}{*}{0.66} \\
\hline & non SRC/mucinous & 35 & 80.9 & 85.7 & 89.4 & 75.0 & 82.8 & \\
\hline \multirow[t]{2}{*}{ Liver } & $\mathrm{SRC} /$ mucinous & 5 & 0 & 50.0 & 0 & 25.0 & 20.0 & \multirow{2}{*}{$0.02 *$} \\
\hline & non SRC/mucinous & 35 & 84.2 & 100 & 100 & 84.2 & 91.4 & \\
\hline \multirow[t]{2}{*}{ Distant } & SRC/mucinous & 19 & 77.7 & 60.0 & 63.6 & 75.0 & 68.4 & \multirow{2}{*}{0.2} \\
\hline & non SRC/mucinous & 79 & 85.1 & 76.0 & 88.4 & 70.3 & 82.2 & \\
\hline
\end{tabular}

Table 5. Impact of PET/CT in clinical decision making

\begin{tabular}{lll}
\hline Before PET/CT & After PET/CT & $\mathbf{n ~ ( \% )}$ \\
\hline Treatment procedure & Treatment procedure & $98(76)$ \\
Routine follow-up & Routine follow-up & $12(9)$ \\
Treatment procedure & Routine follow-up & $10(8)$ \\
Routine follow-up & $\begin{array}{l}\text { Treatment procedure } \\
\text { Treatment procedure }\end{array}$ & $\begin{array}{l}\text { Different treatment } \\
\text { procedure }\end{array}$ \\
\end{tabular}

cancer. On the other hand, De Potter et al. reported that FDG PET might not be suitable as a primary tool for followup due to its moderate accuracy $(14,15,16,22)$. In a recent study Baiocchi et al. concluded that oncological follow-up after radical surgery for gastric cancer should be based mainly on thoracoabdominal CT and 18-FDG-PET (23).

In our results, all values of diagnostic performance except for the specificity value were greater than $75 \%$, and particularly the sensitivity value was up to $91 \%$ on a perperson basis. The lack of diagnostic spesificity in this study is thought to be especially due to low specificity value of locoregional recurrence, causing of false positive FDG uptake in anostomotic site which was the result of postoperational inflammatory changes. Another reason was the low specificity value of distant metastasis, especially caused by mediastinal lymph nodes. As CT part of the PET/CT scan was not diagnostic, it was not always possible to distinguish vascular structures from mediastinal lymph nodes. Also many metabolically active conditions like abdominal organs where physiologic uptakes are commonly found are the gastrointestinal and urinary tracts, can cause FDG uptake, thus can decrease the specificity of PET in detecting malignant lesions (22). These include the inflammatory lesions like granulamatous diseases, diverticulis and gastritis and the benign tumors like colonic adenomas $(24,25)$. But these false positive conditions can be readily detected by side-by-side reviewing of anatomic correlation between PET and CT, thus improving spesificity and positive predictive value.

In some reports, it is mentioned that PET/CT has moderate sensitivity and specificity for detection of gastric cancer recurrence. Needless to say, false negative results mostly reflect their insufficient metabolic activity of a malignant lesion, but its small size can occasionally cause false negative interpretation, particularly in cases of peritoneal metastasis $(16,26,27)$. Also it has been reported that SRC and mucinous adenocarcinoma showed significantly low FDG uptake and thus they can pose false-negative findings $(28,29)$. However, our results were not consistent with these findings, although the number of patients in the $\mathrm{SRC} /$ mucinous adenocarcinoma subgroup was not large $(n=25)$. In our results; in terms of whether or not histology had been SRC/musinous adenocarcinoma, although it was higher in the non SRC/mucinous adenocarcinoma group, the difference in diagnostic accuracy rates were not statistically significant on a per-person $(84.7 \%$ vs. $72.0 \%)$ and per-lesion basis, except for liver metastasis.

It is reported that PET/CT influence patient management and decision making in the significant part of patients in the range of $14 \%$ to $52 \%$. According to our results, after the integration of PET/CT scan in the patients' follow-up, clinical management was changed in 20 (15\%) of patients. Our results were thus competible with those in the literature for modification of treatment planning $(2,30,31)$. In 19 of these 20 patients (95\%), to our knowledge which is the highest per cent of accuracy ever reported, PET/CT had correctly-managed therapy/follow-up plans according to the final diagnosis. 
Our study had several limitations. First, not all the recurred cases were confirmed by histopathological diagnosis. Therefore, there was the possibility of including cases in which false-positive lesions were treated as true-positive lesions by anti-cancer drugs, or true-positive lesions were not identified in the clinical setting. Secondly, 3-month interval may not be enough to confirm the absence of recurrence. In addition, the small sample size may have produced a statistically limited value. Another limitation was the retrospective design, so the suspicion of recurrence and proper indication of 18F-FDG PET/CT scans were not well defined. Because of this, we were unable to standardize the interval and methods of follow-up imaging studies and gastroscopy. This nature also could cause selection bias, because the patients who had not undergone PET/ CT were excluded. Also, as the number of patients with advanced stage was high, our study population might be composed of patients who had a higher possibility of having recurrence.

Despite these deficiencies, our study has significance in giving us evidence of the role of fusion PET/CT in post-operative surveillance and in the clinical decisionmaking process. We suggest that PET/CT is highly useful in detecting or confirming recurrence once a patient with gastric cancer is clinically or radiologically suspicious of recurrence during follow-up. Moreover, our results together with those in the literature demostrate that integrated FDG PET/CT allows optimization of the treatment plan and might play an important role in decision making of treatment. Further well-designed prospective studies enrolling large populations are needed to establish the role of fusion PET/CT in detection of gastric cancer recurrence.

\section{Conclusion}

In conclusion, in spite of several limitations and retrospective design, our results reveal that FDG PET/CT can provide useful information in discriminating true recurrence in patients with suspected gastric cancer recurrence and may have significant impact on clinical decisions/patient management in a considerable percentage of patients.

\section{Conflicts of Interest}

There are no conflicts of interest.

\section{References}

1. Kamangar F, Dores GM, Anderson WF. Patterns of cancer incidence, mortality, and prevalence across five continents: defining priorities to reduce cancer disparities in different geographic regions of the world. J Clin Oncol 2006;24:2137-2150.

2. Sun L, Su XH, Guan YS, Pan WM, Luo ZM, Wei JH, Wu H. Clinical role of 18F-fluorodeoxyglucose positron emission tomography/ computed tomography in post-operative follow up of gastric cancer: initial results. World J Gastroenterol 2008;14:4627-4632.

3. Jemal A, Siegel R, Ward E, Murray T, Xu J, Thun MJ. Cancer statistics, 2007. CA Cancer J Clin 2007;57:43-66.
4. Sano T, Sasako M, Yamamoto $S$, Nashimoto A, Kurita A, Hiratsuka M, Tsujinaka T, Kinoshita T, Arai K, Yamamura Y, Okajima K. Gastric cancer surgery: morbidity and mortality results from a prospective randomized controlled trial comparing D2 and extended para-aortic lymphadenectomy-Japan Clinical Oncology Group study 9501. J Clin Oncol 2004;22:2767-2773.

5. Schwarz RE, Zagala-Nevarez K. Recurrence patterns after radical gastrectomy for gastric cancer: prognostic factors and implications for postoperative adjuvant therapy. Ann Surg Oncol 2002;9:394400.

6. Yoo $\mathrm{CH}$, Noh SH, Shin DW, Choi SH, Min JS. Recurrence following curative resection for gastric carcinoma. Br J Surg 2000;87:236-242.

7. Kodera $Y$, Ito $S$, Yamamura $Y$, Mochizuki $Y$, Fujiwara M, Hibi K, Ito K, Akiyama S, Nakao A. Follow-up surveillance for recurrence after curative gastric cancer surgery lacks survival benefits. Ann Surg Oncol 2003:10:898-902.

8. Whiting J, Sano T, Saka M, Fukagawa T, Katai H, Sasako M. Follow-up of gastric cancer: a review. Gastric Cancer 2006;9:74-81.

9. Kim KW, Choi BI, Han JK, Kim TK, Kim AY, Lee HJ, Kim YH, Choi JI, Do KH, Kim HC, Lee MW. Postoperative anatomic and pathologic findings at CT following gastrectomy. Radiographics 2002;22:323336.

10. Ha HK, Kim HH, Kim HS, Lee MH, Kim KT, Shinn KS. Local recurrence after surgery for gastric carcinoma: CT findings. AJR Am J Roentgenol 1993;161:975-977.

11. Lee JE, Hong SP, Ahn DH, Jeon TJ, KAng MK, Kwon C, Ko, KH, Hwang SG, Park PW, Rim KS. The role of 18F-FDG PET/CT in the evaluation of gastric cancer recurrence after curative gastrectomy. Yonsei Med J 2011;52:81-88.

12. Flamen $P$, Lerut $A$, Van Cutsem E, Cambier JP, Maes $A$, De Wever W, Peeters M, De Leyn P, Van Raemdonck D, Mortelmans L. The utility of positron emission tomography for the diagnosis and staging of recurrent esophageal cancer. J Thorac Cardiovasc Surg 2000;120:1085-1092.

13. Chen LB, Tong JL, Song HZ, Zhu H, Wang YC. (18)F-DG PET/CT in detection of recurrence and metastasis of colorectal cancer. World J Gastroenterol 2007;13:5025-5029.

14. Jadvar H, Tatlidil R, Garcia AA, Conti PS. Evaluation of recurrent gastric malignancy with (F-18)-FDG positron emission tomography. Clin Radiol 2003;58:215-221.

15. Sim SH, Kim YJ, Oh DY, Lee SH, Kim DW, Kang WJ, Im SA, Kim TY, Kim WH, Heo DS, Bang YJ. The role of PET/CT in detection of gastric cancer recurrence. BMC Cancer 2009;9:73.

16. De Potter T, Flamen P, Van Cutsem E, Penninckx F, Filez L, Bormans G, Maes A, Mortelmans L. Whole-body PET with FDG fort he diagnosis of recurrent gastric cancer. Eur J Nucl Med Mol Imaging 2002;29:525-529.

17. Stahl A, Ott K, Weber WA, Becker K, Link T, Siewert JR, Schwaiger M. Fink U. FDG PET imaging of locally advanced gastric carcinomas: correlation with endoscopic and histopathological findings. Eur J Nucl Med Mol Imaging 2003;30:288-295.

18. Jensen EH, Tuttle TM. Preoperative staging and postoperative surveillance for gastric cancer. Surg Oncol Clin N Am 2007;16:329-342.

19. Chen CY, Hsu JS, Wu DC, Kang WY, Hsies JS, Jaw TS, Wu MT, Liu GC. Gastric cancer: preoperative local staging with 3D multi-detector row CT-correlation with surgical and histopathologic results. Radiology 2007;242:472-482.

20. Kang BC, Kim JH, Kim KW, Lee DY, Baek SY, Lee SW, Jung WH. Value of the dynamic and delayed MR sequence with Gd-DTPA in the T-staging of stomach cancer: correlation with the histopathology. Abdom Imaging 2000;25:14-24.

21. Shinya S, Sasaki T, Nakagawa Y, Guiquing Z, Yamamoto F, Yamashita $Y$. The usefulness of diffusion-weighted imaging (DWI) for the detection of gastric cancer. Hepatogastroenterology 2007;54:13781381.

22. Park MJ, Lee WJ, Lim HK, Park KW, Choi JY, Kim BT. Detecting recurrence of gastric cancer: the value of FDG PET/CT. Abdom Imaging 2009;34:441-447. 
23. Baiocchi GL, Marrelli D, Verlato G, Morgagni P, Giacopuzzi S, Coniglio A, Marchet A, Rosa F, Capponi MG, Di Leo A, Saragoni L, Ansaloni L, Pacelli F, Nitti D, D'Ugo D, Roviello F, Tiberio GA, Giulini SM, De Manzoni G. Follow-up after gastrectomy for cancer: an appraisal of the italian research group for gastric cancer. Ann Surg Oncol 2014;21:2005-2011.

24. Kostakoglu L, Hardoff R, Mirtcheva R, Goldsmith SJ. PET-CT fusion imaging in differantiating physiologic from pathologic FDG uptake. Radiographics 2004;24:1411-1431.

25. Blake MA, Singh A Setty BN, Slattery J, Kalra M, Maher MM, Sahani DV, Fischman AJ, Mueller PR. Pearls and pitfalls in interpretation of abdominal and pelvic PET-CT. Radiographics 2006;26:1335-1353.

26. Zou H, Zhao Y. 18FDG PET-CT for detecting gastric cancer recurrence after surgical resection: a meta-analysis. Surg Oncol 2013;22:162-166.

27. Lim JS, Yun MJ, Kim MJ, Hyung WJ, Park MS, Choi JY, Kim TS, Lee JD, Noh SH, Kim KW. CT and PET in stomach cancer: preoperative staging and monitoring of responce to therapy. Radiographics 2006;26:143-156.
28. Kim SK, Kang KW, Lee JS, Kim HK, Chang HJ, Choi JY, Lee JH, Ryu KW, Kim YW, Bae JM. Assessment of lymph node metastases using 18F-FDG PET in patients with advanced gastric cancer. Eur J Nucl Med Mol Imaging 2006;33:148-155.

29. Dassen AE, Lips DJ, Hoekstra CJ, Pruijt JF, Bosscha K. FDG-PET has no definite role in preoperative imaging in gastric cancer. Eur J Surg Oncol 2009;35:449-455.

30. Bar-Shalom R, Yefremov N, Guralnik L, Gaitini D, Frenkel A, Kuten A, Altman H, Keidar Z, Israel O. Clinical performance of PET/CT in evaluation of cancer: additional value for diagnostic imaging and patient management. J Nucl Med 2003;44:1200-1209.

31. Bilici A, Ustaalioglu BB, Seker M, Kefeli U, Canpolat N, Tekinsoy B, Ozugur S, Gumus M. The role of 18F-FDG PET/CT in the assessment of suspected recurrent gastric cancer after initial surgical resection: can the results of FDG PET/CT influence patients' treatment decision making? Eur J Nucl Med Mol Imaging 2011;38:64-73. 